\title{
Strongyloides stercoralis with Gastroduodenal Involvement and Complicated with SIADH: An Unusual Diagnosis to Consider in Immunosuppressed Patients with Hyperemesis and Eosinophilia
}

\author{
María del Mar Díaz Alcázar ${ }^{a}$ Adelina García Robles ${ }^{a}$ Javier Luis López Hidalgo b \\ Dolores Quintero Fuentes ${ }^{a}$ Alicia Martín-Lagos Maldonado ${ }^{a}$

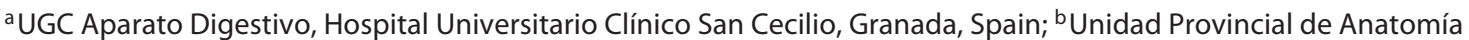 \\ Patológica de Granada, Hospital Universitario Clínico San Cecilio, Granada, Spain
}

Keywords

Strongyloides stercoralis - Hyperinfection syndrome . Hyperemesis - Gastric mucosa - Syndrome of inappropriate secretion of antidiuretic hormone

\section{Abstract}

Strongyloides stercoralis is an intestinal nematode that colonizes and reproduces in the upper small intestinal mucosa. Infection in immunocompetent hosts is self-limited but in immunocompromised patients it can be complicated and cause hyperinfection. We present a 60 -year-old female who was admitted due to an exacerbation of acquired thrombotic thrombocytopenic purpura requiring high doses of corticosteroids. The patient began to experience persistent pyrosis, nausea, vomiting, and oral intolerance. She was diagnosed with syndrome of inappropriate secretion of antidiuretic hormone (SIADH). Upper endoscopy was performed and showed esophageal, gastric, and duodenal mucosa with edema and erythema. Moreover, there were superficial erosions and thickened folds in duodenum. Gastric and duodenal biopsies were taken. Abdominal computed tomography and magnetic enteroresonance displayed duodenal dilation and inflammatory changes. The histological study of biopsies showed colonization by S. stercolaris in the antrum and duodenum. S. stercolaris is a human parasite that is endemic in tropical, subtropical, and temperate regions. Its lifecycle is complex because it completes its entire cycle within the human host; it penetrates the skin, migrates to the lungs, and reach the gastrointestinal tract. The most affected site is the duodenum and upper jejunum. The lifecycle includes autoinfection through the intestinal mucosa or perianal skin, especially in immunocompromised hosts. Immunossuppression can lead to hyperinfection syndrome and disseminated disease. However, involvement of the stomach has relatively rarely been reported. SIADH has been related to systemic hyperinfection, although the mechanism is not clear. The relatively nonspecific clinical and imaging features and the low sensitivity of routine parasite tests make the diagnosis challenging and delayed.

(C) 2021 Sociedade Portuguesa de Gastrenterologia Published by S. Karger AG, Basel karger@karger.com www.karger.com/pjg

Karger $\stackrel{\text { ' }}{5}$ BOPEN ACCESS
C 2021 Sociedade Portuguesa de Gastrenterologia Published by S. Karger AG, Basel

This is an Open Access article licensed under the Creative Commons Attribution-NonCommercial-4.0 International License (CC BY-NC) (http://www.karger.com/Services/OpenAccessLicense), applicable to the online version of the article only. Usage and distribution for commercial purposes requires written permission.
María del Mar Díaz Alcázar

Hospital Universitario Clínico San Cecilio de Granada

Av. de la Investigación, s/n

ES-18016 Granada (Spain)

mmardiazalcazar@gmail.com 


\section{S. stercoralis com envolvimento gastroduodenal complicado com SIADH: um diagnóstico incomum a considerar em doentes imunocomprometidos com vómitos e eosinofilia}

\section{Palavras-Chave}

Strongyloides stercoralis - Sindrome de hiperinfeção · Hiperemese · Mucosa gástrica · Sindrome de secreção inapropriada de hormona antidiurética

\section{Resumo}

Strongyloides stercoralis é um nematódo intestinal que coloniza e se reproduz na mucosa do intestino delgado proximal. A infeção em hospedeiros imunocompetentes é auto-limitada mas em doentes imunocomprometidos pode ter um curso complicado e causar hiperinfeção. Apresentamos um caso de uma mulher de 60 anos que é admitida devido a uma exacerbação de uma púrpura trombocitopénica trombótica adquirida com necessidade de altas doses de corticoides. A doente inicia quadro de pirose persistente, náuseas, vómitos e intolerância alimentar. Faz-se o diagnóstico de síndrome de secreção inapropriada de hormona antidiurética (SIADH). A endoscopia digestiva alta evidencia mucosa gástrica e duodenal com edema e eritema, para além de erosões e pregas espessadas duodenais. O TC e a enteroRMN mostram dilatação duodenal e alterações inflamatórias. A histologia mostra S. stercoralis a colonizar a mucosa do antro e duodeno. O S. stercolaris é um parasita humano, endémico em regiões tropicais e subtropicais. Tem um ciclo de vida complexo já que completa o seu ciclo todo dentro do organismo humano: penetra pela pele, migra para os pulmões e atinge o trato gastrointestinal. Os sítios mais afetados são o duodeno e o jejuno proximal. O ciclo de vida envolve autoinfeção na mucosa intestinal ou pele perianal, especialmente em doentes imunocomprometidos, com a imunodepressão podendo levar a síndrome de hiperinfeção e doença disseminada. Contudo, o envolvimento gástrico é raramente descrito. O SIADH tem sido relacionado com o síndrome de hiperinfeção, contudo, o seu mecanismo não é claro. O relativo inespecífico quadro clínico e alterações imagiológicas, assim como a baixa sensibilidade dos testes de parasitas de rotina atrasam e fazem o diagnóstico desafiante.

(C) 2021 Sociedade Portuguesa de Gastrenterologia Publicado por S. Karger AG, Basel

\section{Introduction}

Strongyloides stercoralis is an intestinal nematode that colonizes and reproduces in the upper small intestinal mucosa [1]. Infection in immunocompetent hosts is self-limited but in immunocompromised patients it can be complicated and cause hyperinfection [1]. Herein, we report a case of hyperinfection syndrome with gastric and duodenal involvement and complicated with syndrome of inappropriate secretion of antidiuretic hormone (SIADH).

\section{Case Report}

The patient is a 60-year-old female from the Dominican Republic who had lived in Spain for 10 years and was diagnosed with acquired thrombotic thrombocytopenic purpura with central nervous system involvement. Two months after the diagnosis she was admitted due to exacerbation of her illness with severe thrombocytopenia, in this case without neurologic symptoms. The evolution was slow, requiring high doses of corticosteroids, several sessions of plasma exchange, and rituximab to achieve remission of the hematological disease. After finishing plasma exchange and when the corticoids were being withdrawn, the patient began to experience persistent pyrosis, nausea, vomiting, and oral intolerance. Physical examination highlights epigastric tenderness. Blood tests showed hyponatremia (sodium $119 \mathrm{mEq} / \mathrm{L}$, reference values 136-146) and leukocytosis with eosinophilia (20,790 leukocytes/ $\mu \mathrm{L}$ with $18 \%$ of eosinophils). The patient presented euvolemic hyponatremia with criteria of SIADH (plasma osmolality $258 \mathrm{mOsm} / \mathrm{kg}$, reference values 275-300; urine osmolality $588 \mathrm{mOsm} / \mathrm{kg}$, reference values 50 $1,200)$. Upper endoscopy was performed, and it showed esophageal, gastric, and duodenal mucosa with edema and erythema (Fig. 1). Moreover, there were superficial erosions and thickened folds in the duodenum. Gastric and duodenal biopsies were taken.

An abdominal computed tomography was performed (without intravenous contrast because the patient was allergic). It showed dilation of the second and third duodenal portions, with wall thickening and rarefaction of the adjacent fat, in relation to inflammatory changes that seemed to affect a segment of about $5 \mathrm{~cm}$ (Fig. 2). Symptoms persisted, so a magnetic enteroresonance was done and mild dilation and slight inflammatory changes were found which affected a segment of about $3 \mathrm{~cm}$ of the second duodenal portion. The involvement seemed to have improved since the previous computed tomography. The histological study of gastric and duodenal biopsies showed colonization of acini by S. stercolaris in both the antrum and the duodenum (Fig. 3). A stool test confirmed infection with this parasite. Treatment of S. stercolaris hyperinfestation with ivermectin and albendazole was initiated, with progressive tolerance and clinical improvement. She completed 18 days of treatment with antihelminthic drugs until repeated stool tests showed no presence of the parasite. Five months later the patient had a new exacerbation of acquired thrombotic thrombocytopenic purpura, which was treated again with glucocorticoids, plasma exchange, and rituximab, but did not show any gastrointestinal symptoms and stool tests remained negative with prophylaxis with ivermectin. 
Fig. 1. Upper endoscopy image showing esophageal (a), gastric (b), and duodenal (c) mucosa with edema and erythema.
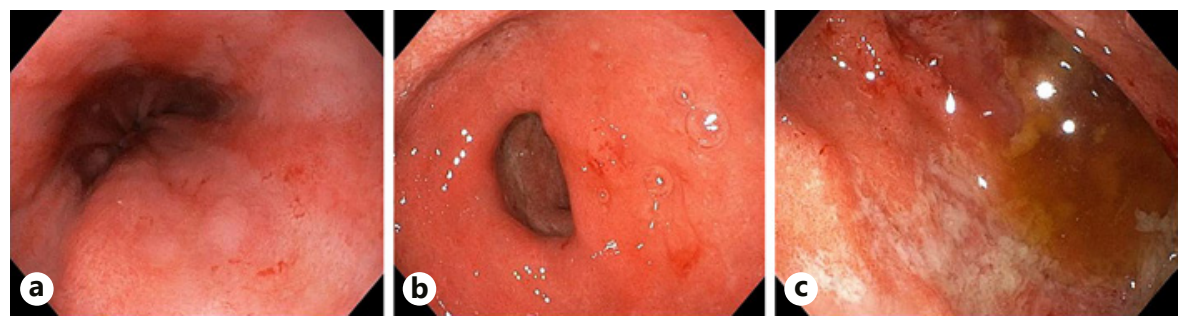

\section{Discussion}

S. stercolaris is a human parasite that is endemic in tropical, subtropical, and temperate regions like Southeastern USA, South Asia, Latin America, and sub-Saharan Africa [2-6]. The incidence of strongyloidiasis is increasing in many developing countries and it is facilitated by international travel and immigration [3]. It is estimated that about 30-100 million people are infected worldwide $[2,4]$.

The lifecycle of $S$. stercolaris is complex because it completes its entire cycle within the human host $[2,4]$. Free-living larvae penetrate the skin and migrate to the lungs via venous circulation $[2-4,6,7]$. They break into the alveolar spaces, ascend through the tracheobronchial tree, and are swallowed with sputum $[4,6,7]$. After reaching the gastrointestinal tract, they invade the small bowel and live buried in the crypts $[2,3,6,7]$. The most affected sites are the duodenum and the upper jejunum, where the larvae develop into adult worms $[2-4,7,8]$. Adult female worms usually reside under the intestinal mucosa, where they shed eggs [3]. Fertilized eggs produce new larvae that exit into the intestinal lumen and are excreted in the feces $[3,4,6,7]$. The life cycle includes autoinfection through the intestinal mucosa or perianal skin, especially in immunocompromised hosts [2-4].

Immunossuppression can lead to hyperinfection syndrome and disseminated disease [2-5, 7]. Strongyloides hyperinfection syndrome occurs when the normal life cycle is augmented, resulting in massive infection of the gastrointestinal tract, the circulatory system, and the lungs [9]. Disseminated strongyloidiasis is when the parasite extends outside of the traditional lifecycle and invades the central nervous system, the liver, the kidneys, and other organs $[2-5,7,9]$. However, involvement of the stomach has relatively rarely been reported $[1,5,7]$. Disseminated strongyloidiasis often occurs in hyperinfection syndrome [9]. Hyperinfection syndrome can progress to organ failure and death $[3,5]$. Hematologic malignancies, transplantation, immunosuppressive drugs such as corticoste-

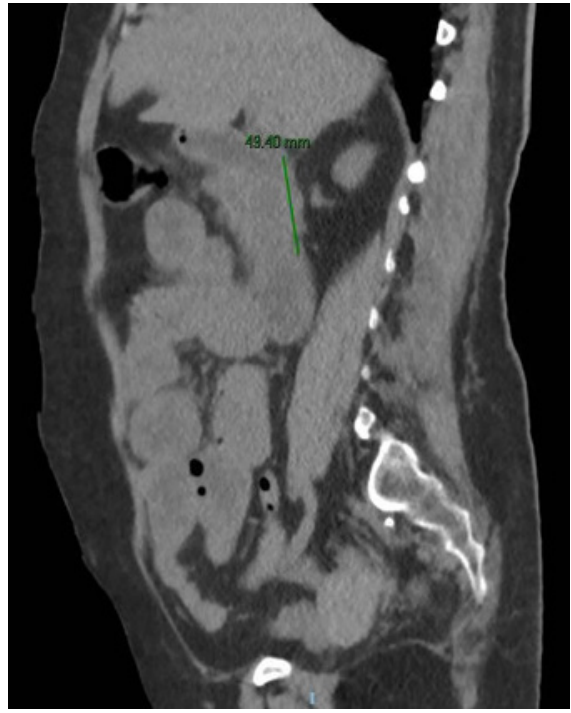

Fig. 2. Abdominal computed tomography image without intravenous contrast showing dilation of the second and third duodenal portions, with wall thickening and rarefaction of the adjacent fat, in relation to the inflammatory changes that seem to affect a segment of about $5 \mathrm{~cm}$.

roids, human T-lymphotropic virus type-1 (HTLV-1), HIV-1, and another immunosuppressed states are risk factors for S. stercolaris hyperinfection syndrome [2-4].

Symptoms are frequently nonspecific, like vomiting, abdominal pain, diarrhea, and weight loss $[3,8]$, although half of the infections are asymptomatic $[2,4,6]$. Malabsorption syndromes, gastrointestinal bleeding, intestinal obstruction, SIADH, and sepsis have also been described $[2-4,6,8]$. SIADH has been related to systemic strongyloidiasis hyperinfection and likely attributed to central nervous system or pulmonary involvement, although the mechanism is not clear $[4,10]$. Tariq et al. [4] reviewed previous reported cases of SIADH in Strongyloides infection and found only 8 cases. All of them recovered with antihelminthic treatment [4].

The relatively nonspecific clinical and imaging features and the low sensitivity of routine parasite tests make 
Fig. 3. Histological cut of gastric mucosa with hematoxylin and eosin staining showing colonization of acini by $S$. stercolaris (arrows).

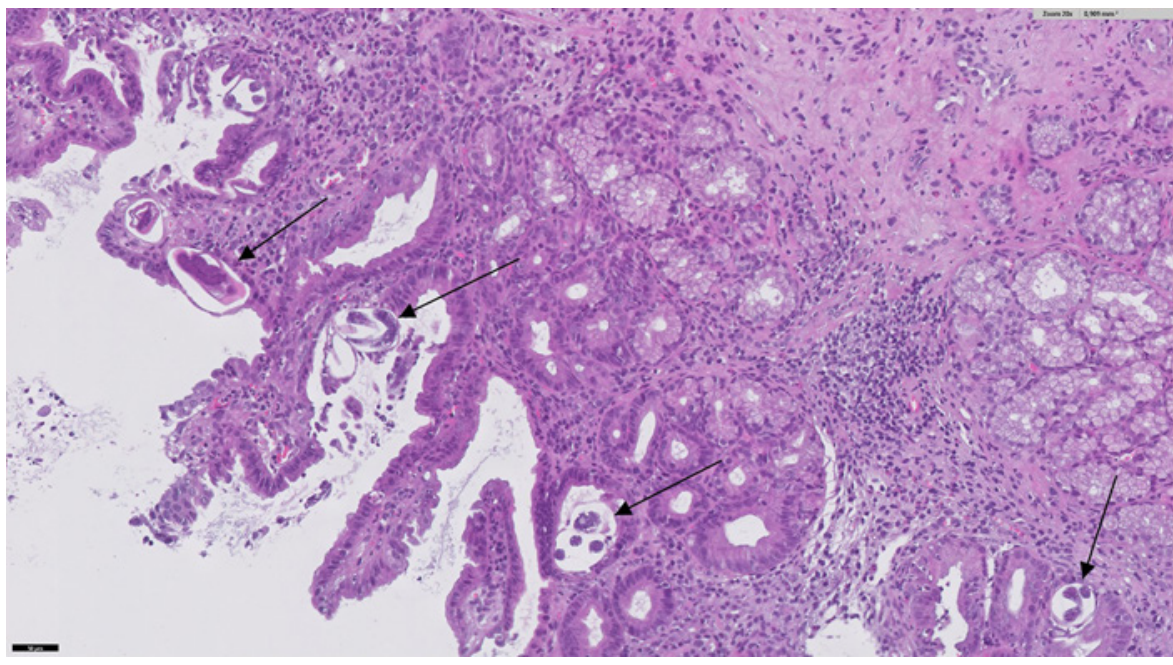

the diagnosis challenging and delayed $[4,10]$. Peripheral eosinophilia is variable $[4,8,10]$. Definitive diagnosis is usually made on direct visualization of larvae in stool or in clinical specimens such as intestinal aspirates or biopsies from endoscopy [10]. Single fecal sample examination has a low sensitivity due to the low parasite burden or intermittent excretion $[4,10]$. Repeated examinations with up to 7 stool samples may increase the sensitivity [4, 10]. Serologic tests may be used to overcome the limitations of stool tests, with a greater sensitivity and a high negative predictive value, which is useful for exclusion of S. stercoralis infection [11]. The most common endoscopic findings are mucosal edema, erythema, friability, white villi, erosion, and pseudopolyps [8].

The treatment of choice for S. stercolaris hyperinfection is ivermectin [2]. The alternatives are benzimidazolebased agents like albendazole and thiabendazole [2]. The optimal duration of antihelminthic treatment for hyperinfection or disseminated strongyloidiasis is uncertain [11]. It is recommended that the treatment be continued until the symptoms have resolved and stool tests are negative for at least 2 weeks [11]. For patients with persistent immunosuppression whose symptoms have resolved, ivermectin once monthly can be given as prophylaxis [11].

To conclude, we present the case of a patient with hyperemesis and oral intolerance in relation to duodenal inflammation caused by $S$. stercolaris. She suffered from reactivation of chronic infestation due to immunosuppression in the context of the treatment of purpura thrombotic thrombocytopenic. S. stercoralis infection and hyperinfection syndrome are rare in our environment.
Apart from the low prevalence, the diagnosis of the infection is challenging. The lack of specific clinical features results in frequent misdiagnosed cases. Moreover, in this patient there was gastric involvement and SIADH, which have rarely been reported.

\section{Statement of Ethics}

This paper was written in accordance with the ethical guidelines of the World Medical Association Declaration of Helsinki of 1975 , revised in 2013 . The patient provided written informed consent for publication of this case.

\section{Conflict of Interest Statement}

There are not conflicts of interests to disclose.

Funding Sources

There are no funding sources to disclose.

\section{Author Contributions}

Conception and design: María del Mar Díaz Alcázar, Adelina García Robles, Dolores Quintero Fuentes, and Alicia Martín-Lagos Maldonado. Drafting of this article: María del Mar Díaz Alcázar and Alicia Martín-Lagos Maldonado. Critical revision: Javier Luis López Hidalgo, Adelina García Robles, and Dolores Quintero Fuentes. Final approval: María del Mar Díaz Alcázar, Adelina García Robles, Javier Luis López Hidalgo, Dolores Quintero Fuentes, and Alicia Martín-Lagos Maldonado. 


\section{References}

1 Yaldiz M, Hakverdi S, Aslan A, Temiz M, Culha G. Gastric infection by Strongyloides stercoralis: a case report. Turk J Gastroenterol. 2009 Mar;20(1):48-51.

2 Shields AM, Goderya R, Atta M, Sinha P. Strongyloides stercoralis hyperinfection presenting as subacute small bowel obstruction following immunosuppressive chemotherapy for multiple myeloma. BMJ Case Rep. 2014 Jan;2014:bcr2013202234.

3 Wang C, Xu J, Zhou X, Li J, Yan G, James AA, et al. Strongyloidiasis: an emerging infectious disease in China. Am J Trop Med Hyg. 2013 Mar;88(3):420-5.

4 Tariq H, Kamal MU, Reddy P, Bajantri B, Niazi M, Matela A, et al. Anemia, intractable vomiting, chronic diarrhea, and syndrome of inappropriate antidiuretic secretion: a diagnostic dilemma: Disseminated strongyloido- sis in a patient with newly diagnosed HTLV infection-case report and review of literature. Medicine (Baltimore). 2017 Dec; 96(52):e9229.

5 Patra AA, Nath P, Pati GK, Panigrahi SC, Mallick B, Acharya JC, et al. Strongyloides infection presenting as proximal small intestinal obstruction. ACG Case Rep J. 2019 Jun; 6(6): $\mathrm{e} 00124$.

6 Koczka CP, Hindy P, Goodman A, Gress F. Strongyloidiasis: a diagnosis more common than we think. Eur J Gastroenterol Hepatol. 2012 Jul;24(7):860-2.

7 Kim J, Joo HS, Kim DH, Lim H, Kang YH, Kim MS. A case of gastric strongyloidiasis in a Korean patient. Korean J Parasitol. 2003 Mar;41(1):63-7.

8 Santos RB, Fonseca LE Jr, Santana AT, Silva CA, Guedes JC. Clinical, endoscopic and his- topathological profiles of parasitic duodenitis cases diagnosed by upper digestive endoscopy. Arq Gastroenterol. 2011 Oct-Dec;48(4): 225-30.

9 Ramdial PK, Hlatshwayo NH, Singh B. Strongyloides stercoralis mesenteric lymphadenopathy: clue to the etiopathogenesis of intestinal pseudo-obstruction in HIV-infected patients. Ann Diagn Pathol. 2006 Aug;10(4): 209-14.

10 Chowdhury DN, Dhadham GC, Shah A, Baddoura W. Syndrome of inappropriate antidiuretic hormone secretion (SIADH) in Strongyloides stercoralis hyperinfection. J Glob Infect Dis. 2014 Jan;6(1):23-7.

11 Leder K, Weller PF. Strongyloidiasis. In: Ryan ET, ed. Up-to-date [Internet]. Waltham (MA): UpToDate; 2020 [cited 2020 Nov 1]. Available from: http://www.uptodate.com. 